\title{
Linking Self-Employment Before and After Migration: Migrant Selection and Human Capital
}

\author{
Andrey Tibajev
}

Linköping University

Abstract: In linking self-employment before and after migration, the often-cited home-country selfemployment hypothesis states that immigrants who come from countries with large self-employment sectors are themselves more likely to have been self-employed and hence have a higher propensity for self-employment in their destination country. Using Swedish data, this study shows that the first part of the hypothesis, that origin-country average rates of self-employment can be used to approximate individual experience, is false; but the second part, the connection between self-employment before and after migration, is true if the measurement is done on the individual level. Migrants who have been self-employed before migration accumulate entrepreneurial human capital, making future self-employment a more desirable labor market alternative vis-à-vis wage employment. But because of migrant selection, this association cannot be captured by aggregate measures, and this is the reason why the home-country self-employment hypothesis, although intuitive, has underperformed in previous empirical tests.

Keywords: migration; entrepreneurship; human capital; event-history analysis; Level-of-Living Survey

Citation: Tibajev, Andrey. 2019. "Linking Self-Employment Before and After Migration: Migrant Selection and Human Capital." Sociological Science 6: 609634.

Received: October 7, 2019

Accepted: October 16, 2019

Published: November 20, 2019

Editor(s): Jesper Sørensen, Olav Sorenson

DOI: $10.15195 / \mathrm{v} 6 . \mathrm{a} 23$

Copyright: (C) 2019 The Author(s). This open-access article has been published under a Creative Commons Attribution License, which allows unrestricted use, distribution and reproduction, in any form, as long as the original author and source have been credited. (C) (i)
$\mathrm{T}^{\mathrm{N}}$ the research field of migrant entrepreneurship, a common way of explaining 1 the variation in immigrants' propensity for self-employment is with variables connected to human capital (Aliaga-Isla and Rialp 2013; Alvarez, Agarwal, and Sorenson 2005; Zhou 2004). Among these explanations, the so-called home-country self-employment hypothesis (Yuengert 1995) takes a central role by explicitly linking experience of self-employment before and after migration. The hypothesis states that immigrants who come from countries where self-employment is prevalent have a higher probability of themselves been self-employed and therefore also have a higher propensity of becoming self-employed in their destination country. The implied causal mechanism is that previous experience of self-employment increases its future attractiveness as a labor market strategy relative to wage employment.

Yet, although this explanation relies on an intuitively strong causal link, that is, that immigrants who have been self-employed before are more likely to become self-employed in the future, the empirical evidence for the home-country self-employment hypothesis has been surprisingly weak. The two earliest tests of the hypothesis by Yuengert (1995) and Fairlie and Meyer (1996), using US data, showed opposite results, and the most comprehensive test by van Tubergen (2005) rejected the hypothesis altogether. This is a fundamental problem for the field. Both economic (Borjas 1986) and sociological (Kloosterman and Rath 2001) accounts of immigrants' propensity for self-employment rely on the capabilities of the individual, and if previous experience of self-employment does not empirically amount to capability, what does? 
The main argument of this study is that the home-country self-employment hypothesis-how it is formulated and how it has been used in previous researchcomprises two separate parts, and it is the combination of these parts that has prevented confirmation of the hypothesis. The first part is an assumption that if an immigrant comes from a country with a large self-employment sector, then he or she will also be more likely to have been self-employed before migration. This part has to do with measurement, the idea that origin-country average rates of selfemployment can be used as a valid approximation of individual-level experience before migration. I call this the country-of-origin approximation assumption. The second part is an implied causal relationship on the individual level, between labor market experience before and labor market experience after migration, the idea that individuals with a specific form of human capital, an entrepreneurial human capital, are also more likely to use that human capital. That is, immigrants who have been self-employed in their countries of origin have a higher propensity for self-employment in their country of destination. I call this the entrepreneurial human capital hypothesis.

The aim of this study is to show that origin-country self-employment rates are neither a good approximation for the individual experiences of migrants in their countries of origin nor a valid predictor of propensity for self-employment in the destination country; that is, the country-of-origin approximation assumption is false because migrant selection makes results based on aggregate measures succumb to ecological fallacy. The aim is also to show that experience of self-employment in the country of origin has a strong and robust association with immigrants' propensity for self-employment in the destination country; that is, the entrepreneurial human capital hypothesis is true.

The empirical analysis is based on data from the Level-of-Living Survey for Foreign Born and Their Children $(N=2,041)$, a high-quality Swedish survey that contains a comprehensive employment biography with information on the respondents' labor market activities from both before and after immigration. Using the information on experience of self-employment before migration, it is possible to both test whether country-of-origin average rates of self-employment are a good approximation for individual experience (see arrow 1a in Figure 1) and contrast individual-experience versus origin-country average rates as predictors of the propensity for self-employment in Sweden (arrows $1 \mathrm{~b}$ and 2 in Figure 1).

\section{Theoretical Background}

\section{Home-Country Self-Employment Hypothesis}

In the original formulation from Yuengert (1995:196), the home-country self-employment hypothesis reads:

Many immigrants come from countries with relatively large self-employed sectors. They are more likely to have been self-employed in the country of origin, or to at least have had some exposure to and training in small business. Experience in the informal sector is a form of sector-specific 


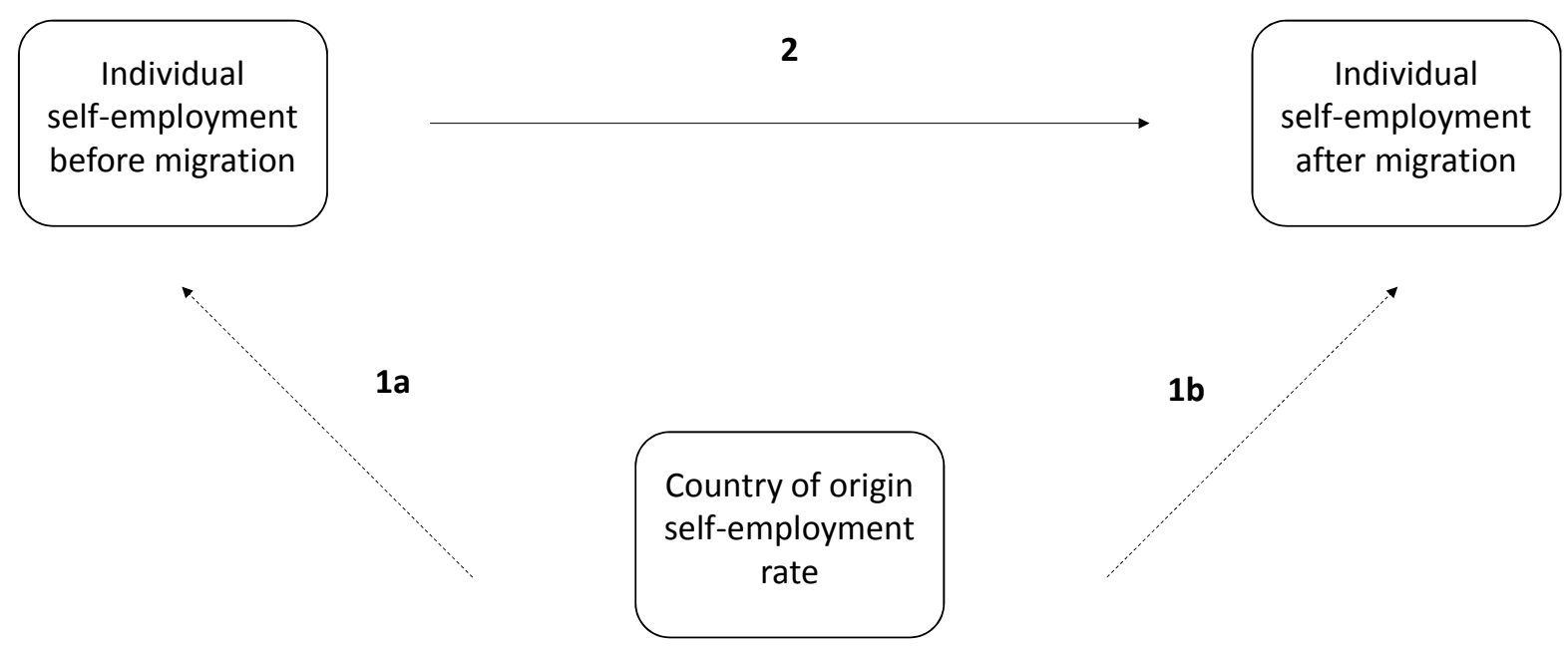

Figure 1: Home-country self-employment hypothesis.

human capital, inclining immigrants more towards self-employment in the [destination country].

Using 1980 US census data, Yuengert (1995) did indeed find a significant relationship between the share of self-employed individuals in the origin country relative to the United States and the proportion of immigrants across different categories in self-employment compared with the native population. However, retesting the hypothesis with 1990 US census data, and excluding natives, Fairlie and Meyer (1996) were unable to find any support for it.

The most comprehensive test of the home-country self-employment hypothesis to date came from van Tubergen (2005), who studied 17 Western destination countries and concluded that there is no association between the self-employment rate in the origin country of an immigrant and the probability of being self-employed in the destination country. For the Swedish case, Hammarstedt and Shukur (2009) found no general support for the hypothesis for immigrants from 17 origin countries and, using a quantile regression, found a correlation between origin-country average rates of self-employment and propensity for self-employment only for immigrants with the very highest propensities. ${ }^{1}$ Partial support for the hypothesis comes from Aharon (2017), who found an association between the female self-employment rate in origin countries and probability of self-employment vis-à-vis wage employment for immigrant women from 28 countries who live in the United States.

Indirect tests of the home-country self-employment hypothesis have also been performed when country or region of origin has been included as an independent variable in analyses of the propensity for self-employment, interpreting the differences across origins in terms of traditions of self-employment. That line of argument relies more on the idea of ethnic capital or culture (Light 1984), but the construction of the argument is the same. It reads that if immigrants come from countries with a large self-employment sector, they also have more of an entrepreneurial culture, which in turn affects the propensity for self-employment. 
Empirically, Li (2001) found for the Canadian case that immigrants from Europe, the United States, and West Asia have a higher probability of being self-employment than immigrants from the rest of Asia, Latin America, and Africa. Lofstrom (2002), in the United States, found that immigrants from the Middle East and North East Asia had the highest rates of self-employment, whereas immigrants from South East Asia and the Caribbean had the lowest. In Sweden, the highest proportion of self-employment was found among immigrants from the Middle East and Western Europe, and the lowest proportion was seen among those from Latin America and Africa (Andersson et al. 2013). The problem with these variations across different origins is that they do not correspond to origin self-employment rates in any meaningful way that would support the home-country self-employment hypothesis.

All of the above-mentioned studies use origin-country average rates of selfemployment in their analyses, as is prescribed by the home-country self-employment hypothesis. In one working paper, Akee, Jaeger, and Tatsiramos (2013) instead used individual-level experience of self-employment in the origin country, taking it as a predictor of self-employment in the destination country. The authors estimated a statistically significant correlation between individual experience of origin-country self-employment and the probability of currently being self-employed rather than in wage employment, using a sample from the 2003 wave of the New Immigrant Survey in the United States. They also tested origin-country average rates of selfemployment for the prediction, with the result being that these have a negative effect on the probability of currently being self-employed, that is, the opposite effect. The current study adds to the research field by including a representative sample for immigrants in a country, using finer measurements for origin-country self-employment rates, using a better operationalization of propensity for self-employment, and most importantly, explicitly testing the country-of-origin approximation assumption.

\section{Country-of-Origin Approximation Assumption}

As seen in the Yuengert quote in the previous section, the argument of the homecountry self-employment hypothesis involves two steps. First, there is a positive correlation between the self-employment rate in the origin country and individual experience of self-employment, and second, this experience increases propensity toward self-employment in the destination country. This way of reasoning, of taking an implied causal mechanism at the individual level and measuring it at the country level, is not unique to Yuengert (1995). On the contrary, it is the norm. Hammarstedt and Shukur (2009:745) make the same connection, writing "immigrants who originate from countries with a large self-employment sector prefer self-employment in the host country, since such immigrants are more likely to have been self-employed". van Tubergen (2005:711) writes that "immigrants [from countries with relatively large self-employment sectors] are more likely to have self-employed parents, to have been exposed to formal training in small business, or to have been self-employed themselves in their countries of origin."

This assumption that there is a positive correlation between the size of the self-employment rate in the country of origin and the probability of individual 
experience of self-employment before migration (arrow 1a in Figure 1), and thus that origin-country average rates can be used as a valid approximation of individual experience in correlation with propensity for self-employment after migration (arrow $1 \mathrm{~b}$ in Figure 1), rests entirely on there being no substantial migrant selection processes that are correlated with human capital or labor market experience in the country of origin. That is, only if migrants are as good as randomly selected out of their origin countries and into their destination countries does this assumption hold.

This is of course not the case. In recent years, there has been an increased focus on migrant selection and in some cases its connection to labor market outcomes (e.g., Birgier et al. 2018; Haberfeld and Lundh 2014; Ichou 2014; Polavieja, FernándezReino, and Ramos 2018; van de Werfhorst and Heath 2019). This is hardly surprising because theories of international migration at their core stipulate how individuals succumb to different processes of nonrandomness (Lee 1966; Massey et al. 1993). In neoclassical economics, it is relative differences in return to human capital and in magnitudes of income distribution between origin and destination countries (Borjas 1989); in dual labor market theory, how structural demand for cheap immigrant labor in the secondary sector in destination countries acts as a pull factor for migration (Piore 1979); and in the life-course approach, migration is connected to other demographic events such as transition to higher education or new employment (Boyle, Halfacree, and Robinson 2013; Warnes 1992). This is to name just a few examples of such theories with a connection to human capital. In addition, many causes of forced displacement in the form of wars, revolutions, or ethnic and religious persecution are by definition selective in who they target. And destination countries can include human capital selection in their immigration policies (de Haas, Natter, and Vezzoli 2018). Ignoring all this, as the country-of-origin approximation assumption does when individual experience is measured at the aggregate level, introduces a major bias into the analysis.

Most of this previous research on selection has focused on education. To my knowledge, this is the first study that explicitly looks at migrant selection connected to the experience of self-employment and how this selection affects propensity for self-employment in the destination country by transmission of entrepreneurial human capital across borders.

\section{Entrepreneurial Human Capital Hypothesis}

In the classic human capital formulation, individuals choose self-employment above wage employment if self-employment is perceived to have a higher financial reward net of the initial investment cost within liquidity constraints and the higher risk of owning a business (Borjas 1986; Evans and Jovanovic 1989). Thus, immigrants who have already been self-employed and consequently built up some experience and ability in the task of running a business (i.e., entrepreneurial human capital) will see higher perceived financial rewards in future self-employment and will thus have a higher propensity to choose self-employment again. This is the causal mechanism of the entrepreneurial human capital hypothesis (arrow 2 in Figure 1). 
The simplicity of the human capital perspective has received ample critique from perspectives emphasising the embeddedness of the entrepreneur and the link between individual agency and social structure (Dahl and Sorenson 2009; Kloosterman and Rath 2001; Sorenson and Audia 2000). Firstly, immigrants are not only pulled into self-employment by the chances of higher rewards but also pushed into it due to unemployment or other barriers in the regular labor market (Abada, Hou, and Lu 2014; Blume et al. 2009; Clark and Drinkwater 2000; Light 1984). Secondly, immigrants must have the ability to choose self-employment, which legal and other barriers can hinder (Kloosterman 2010). Thirdly, because of barriers and, on average, a weaker economic and labor market position compared to natives, immigrants tend to start businesses in labor-intensive and capital-extensive (ethnic) niche markets, where they can rely on the financial and social capital as well as labor of their network (Aldrich and Waldinger 1990; Kloosterman, van der Leun, and Rath 1999).

This account of migrant self-employment provides a more realistic view compared to a strict human capital perspective, yet it is compatible with the entrepreneurial human capital hypothesis. Not all immigrants accrue networks and other resources, not all overcome whatever barriers there may be to starting a business, and not all, regardless of labor market position and for whatever reason, take the step over to self-employment. What the hypothesis states is that the propensity to do all this is higher for immigrants who have been self-employed in the past net of the social structure.

It is also possible to use a culturally driven explanation, instead of human capital accumulation, within the home-country self-employment hypothesis connected to the idea of entrepreneurial culture or resources on a group level (Light 1984). Aharon (2017), for example, interprets the origin-country self-employment rates as norms and values connected to entrepreneurship. This interpretation assumes either that norms of entrepreneurship are evenly distributed across an entire origin population, be it country or region (a far-reaching assumption) or, again, that immigrants are randomly selected so that an aggregate measure can be a valid approximation of individual norms. This view is contested. Both Aldrich and Waldinger (1990) and Fairlie and Meyer (1996) emphasised that there are historical examples in the United States that both support and contradict the cultural explanation. It also seems to be the case that immigrants are often selected on the basis of orientations (i.e., norms and values) toward economic activity (Polavieja et al. 2018) and are not necessarily representative of any kind of nationally prominent culture, creating the same kind of ecological fallacy within the home-country self-employment hypothesis as for the human capital version of the explanation.

\section{Swedish Context}

The history of immigration to Sweden, at least with regard to net immigration, can briefly be described as beginning with labor market migrants, and to a smaller degree refugees, from Europe after World War II; moving on to refugee and family migration from Latin America, Asia, and Africa in the 1970s; and adding the free movement of the European Union (EU) in recent decades (Lundh and Ohlsson 1999). 
Self-employment was strictly regulated, with high entry barriers for foreigners and noncitizens until 1968, but became increasingly deregulated and accessible with reforms during the 1970s and 1990s (Government of the Kingdom of Sweden 1999). At the same time, the Swedish economy experienced the same processes of restructuring and labor market informalization as the rest of the Western world (Slavnic 2010). The changes in both the immigrant population and the economy created a situation where immigrants had been on parity with natives in the labor market but, starting in the 1980s, began to see a lower employment rate and lower incomes (Ekberg and Hammarstedt 2002; Rosholm, Scott and Husted 2006). The ethnic penalties in the labor market are connected to an ethnic structure and segregation of work, an uneven distribution of social capital, discrimination, and problems with the transfer of human capital across national contexts (Andersson Joona and Wadensjö 2012; Behtoui and Neergaard 2010; Bursell 2014; Tibajev and Hellgren 2019; Tomaskovic-Devey, Hällsten, and Avent-Holt 2015).

The self-employment rate among immigrants is, depending on the definition, approximately 10 to 15 percent, which is on par with the native-born population (Andersson et al. 2013; Ohlsson, Broomé, and Bevelander 2012). Self-employed immigrants in Sweden have lower incomes than wage-employed immigrants (Hjerm 2004). Some categories of self-employed immigrants, in particular those coming from outside Europe or the West, also have lower incomes (Andersson Joona 2011) and a higher probability of exiting self-employment into unemployment compared with natives (Andersson Joona 2010). In addition, self-employment has a negative impact on future wage-employment incomes (Andersson 2011). A restructured and deteriorating labor market situation for immigrants, coupled with the fact that self-employment seems to be a suboptimal labor market position for large immigrant categories, highlights the importance of accounting for the blocked mobility perspective when studying propensity for self-employment, and this will be incorporated in the analyses.

\section{Data and Methods}

\section{Data and Sample}

Data comes from the Level-of-Living Survey for Foreign Born and Their Children (Migrant-LNU), a survey conducted specifically for the migrant population at the same time as the 2010 wave of the regular Level-of-Living Survey in Sweden (Swedish Institute for Social Research 2017). It was conducted from 2010 to 2012 (78 percent of the interviews were in 2011) and had a response rate of 49.9 percent for the whole interview, with 3,448 respondents. The definition of a foreign-born migrant used in the survey, and consequently here, is a person who is foreign born, with both parents being foreign born, and who is not adopted. Migrant-LNU also delimits itself to only include migrants who have been living in Sweden for at least five years. The survey used a stratified sample approach to enable comparison between immigrant categories, with seven regions of origin multiplied by three age categories for a total of 21 strata. As a consequence, all analyses and all presentations in tables and figures in this study carry a poststratification weighting that also takes 
into account the differences in response rates across different strata (the exception is sample size, which is always presented unweighted), and all standard errors are robust.

The analytical sample used here consists of those who migrated to Sweden between the ages of 18 and 64 . The restriction serves two purposes. Firstly, because the study concerns labor market activities in Sweden, only those of working age are relevant. Secondly, the comparison between individual-level experience and country-level average rates of self-employment is only reasonable if the included population has been at risk of self-employment before migration. Including childhood migrants makes little sense in this regard. Including immigrants who migrated between the ages of 18 and 64 means that these individuals have been of working age both before and after migration. Limiting the sample this way, together with some minor case-wise exclusions due to missing variables, restricts the sample to 2,041 individuals.

\section{Analytical Strategy}

The analysis will be done in two steps, corresponding to the double aim of the study. The first step concerns the selection and measurement of experience of self-employment (arrow 1a in Figure 1). This is done rather straightforwardly with an ordinary least square regression (OLS), wherein country-of-origin average rates of self-employment predict individual-level experience. If there are no serious selection problems, then the former should be informative of the latter. The second step analyzes immigrant propensity for self-employment in Sweden, and its connection to entrepreneurial human capital, contrasting aggregate and individual measures of premigration experience (arrows $1 \mathrm{~b}$ and 2 in Figure 1). Here as well, if the country-of-origin approximation assumption is true, then the results should be the same regardless of the measure. And if the entrepreneurial human capital hypothesis is true, then there should be a positive association.

Previous research has found a complex and varying relationship between time spent in the destination country and propensity for self-employment (Drinkwater and Clark 2009; Kanas, van Tubergen, and van der Lippe 2009; Le 2000; Li 2001). On the one hand, being in the destination country implies an accumulation of host-country-specific human capital, social contacts, knowledge about potential opportunities, and so on, which all increase the pull factors toward self-employment by making the perceived rewards higher and the start-up costs lower. On the other hand, the same accumulation also reduces the push factors by making it easier to overcome barriers to wage employment. Taken together, there is no reason to a priori assume any kind of linear or otherwise simple form of transition rate over time into self-employment

The Cox proportional hazards regression (Cox 1972) has the advantage of making no such assumption about this baseline transition rate. It is a so-called semiparametric event-history analysis model in that it is fully flexible regarding the underlying distribution of, here, the transition into self-employment, but the ratio of the probability of transition between individuals with different values of included variables is constant over the entire process. 
The basic fitted model has the following form:

$$
h\left(t \mid x_{k}\right)=h_{0}(t) \times \exp \left(\beta_{k} x_{k}\right)
$$

$\mathrm{h}\left(\mathrm{t} \mid \mathrm{x}_{k}\right)$ is the instantaneous probability of entering first self-employment at time $t$ for those who had not yet entered first self-employment, conditional on the values of included variables $x_{k}$. This is the operationalization of the propensity for self-employment in this study. ${ }^{2} h_{0}(t)$ is the baseline transition rate into first self-employment, and $\exp \left(\beta_{k} \mathrm{x}_{k}\right)$ is the ratio of transition rates between individuals with different values on included variables. Thus, when the origin-country average rates of self-employment or individual experience are included in the model, for example, the exponentiated value of $\beta$ for these variables will show by how much the propensity for self-employment is, on average, affected by them.

There is an additional advantage of using a longitudinal event-history setup and measuring entry into self-employment compared to the previously commonplace cross-sectional analysis. ${ }^{3}$ Because the start of self-employment only happens at one point in time, but the ongoing operation of it continues onward throughout time, what is really analyzed with a cross-sectional design is much more the ability aspect of self-employment rather than the propensity to enter self-employment. ${ }^{4}$ This becomes especially true for designs in which self-employment is contrasted with wage employment (i.e., ignoring unemployment) because what is measured then is the ability to keep a small business alive versus the ability to keep a job. Because the Borjas (1986) human capital model is about choice, not ability, entry into self-employment is a better operationalization of that choice than who is currently self-employed at a given point in time. The latter will be tested, with the common cross-sectional design, as a robustness check.

\section{Variables}

\section{Measures of Self-Employment}

Turning first to origin-country rates of self-employment, a question regarding operationalization of the home-country self-employment hypothesis is at what point(s) in time to measure the self-employment rate. All cited previous research uses single-year records of the self-employment rate, that is, that all immigrants from one country or region get the same rate regardless of their year of migration. ${ }^{5}$ The problem with using single-year measures is that self-employment rates vary over time, and individuals who grow up and emigrate from countries of origin 20 or 30 years apart might not be exposed to the same economic structure (or entrepreneurial culture) and therefore, by the logic of the country-of-origin approximation, have different probabilities of having been self-employed (or different norms toward self-employment). To test the home-country self-employment hypothesis properly, the goal must be to use a multiple-years measure of the self-employment rate. That being said, the data is irregular, for obvious reasons, especially for early years and outside Western countries. Nonetheless, important variation is lost when all individuals from the same country are grouped together. 
Here, the individual years of immigration are used as anchors. If data from that year exists for a specific country, that self-employment rate is recorded for all individuals in the sample who migrated to Sweden that year. If not, the closest year to the year of migration is used (with the year before migration being preferred in ties). In this study, the sample of 2,041 individuals came from 132 countries with 1,111 combinations of country-immigration years. Their origin-country selfemployment rates are measured with 669 unique data points using the International Labour Organization (ILO) Yearbooks for Labour Statistics from 1971 to 2000, the ILO database on status in employment (International Labour Organization 2019), and ILO modeled estimates (International Labour Organization 2018) ${ }^{6}$. There are, on average, approximately 3.5 years of deviation between the year of immigration and the year of the recorded self-employment rate (see Table S1 in the online supplement for more information).

Another question is how to define the self-employment rate. The ILO includes unpaid, or contributing, family workers who are helping in a family-run business but are not considered business partners themselves. On the one hand, if they partake in the daily business by dealing with suppliers and customers, handling finances, marketing and bookkeeping, and so on, they also acquire entrepreneurial human capital. As family members, they probably also de facto bear some of the financial risk. On the other hand, a high national prevalence of unpaid family workers can be indicative of a specific business structure, for example, a lot of agriculture, or a stage in economic development that might affect the results. In this study, both the measures of origin-country self-employment without family workers (OCSE) and origin-country self-employment with family workers (OCSE_FW) are used.

Region of origin is included as an approximation of self-employment traditions at the most aggregate levels because this has been done in some previous research. The variable is divided into seven categories: Nordic; Western Europe, North America, and Oceania (EU15+); the rest of Europe; the Middle East and North Africa; the rest of Africa; the rest of Asia; and Latin America.

Individual-level experience of self-employment before migration is a categorical variable with three categories: no (labor market) experience, experience of employment only, and experience of self-employment. It is useful to contrast individuals with experience of employment only with those who have been self-employed before migration when predicting propensity for self-employment in Sweden because the entrepreneurial human capital hypothesis predicts a specific connection to the human capital acquired from previous experience of self-employment in particular, not to human capital or employment in general. As the questionnaire for Migrant-LNU is designed, contributing family workers are included as being self-employed.

Propensity for self-employment in Sweden, the dependent variable in the Cox regression model, is time to entry into first self-employment measured from the year and month of immigration to the year and month of entry, with self-employment being a binary variable coded 0 or $1 .^{7}$ Only self-employment in Sweden counts in the analysis; thus, self-employment elsewhere is coded as 0 . 


\section{Control Variables}

Included basic demographic control variables are immigration age (including a quadratic expression) and gender. The former is included because the more time a person spends in the labor market, the more time that person has to gain experience, including self-employment. The latter is included because self-employment rates differ between men and women, both in Sweden and the world at large (International Labour Organization 2019), and because immigrant men and women choose self-employment within different opportunity structures and power hierarchies (Aharon 2017; Webster and Haandrikman 2017).

To account for levels of general human capital, education is included as a control. It would be preferable to have a variable of the education level at migration or a time-varying variable of education level over the time spent in Sweden. Unfortunately, this is not possible with Migrant-LNU. The best variable available is highest education level achieved at the time of the survey interacted with whether the highest level is achieved in Sweden or abroad. Education level is coded in three categories: primary, upper secondary, and postsecondary education.

Parents' experience of self-employment is positively associated with their children's propensity to become self-employed (Andersson and Hammarstedt 2011; Dunn and Holtz-Eakin 2000) though Hout and Rosen (2000) showed that migration can disrupt this connection. Including parents' experience is thus a way to control for intergenerational transmitted human capital and any cultural inclination toward self-employment that self-employed parents might have bestowed on their offspring. The variable is binary coded: 1 if any parent was self-employed during the childhood of the respondent and 0 if no parent was or if the respondent had no parents growing up.

Individuals migrating for different reasons are subjected to both different selection processes before arriving and differing entry conditions and labor market paths when in their destination country (Zwysen 2019); migration reason is therefore a crucial control variable. However, an important part of the Cox regression model is the proportionality assumption (Blossfeld, Golsch, and Rohwer 2007), that is, the ratio of transition between individuals with different values on a variable is indeed proportional across the entire process. When tested, migration reason was the variable that violated this assumption. This is most likely a reflection of the diverging paths that immigrants with different reasons for migrating have in the labor market. To accommodate this, the Cox regression is stratified by migration reason, which means that the transition rate into self-employment varies freely between migration reason categories but is proportional within them for all other variables. The variable is coded in three categories: work, studies, or other ${ }^{8}$; family; and refuge.

An important social condition is the contacts that immigrants both bring with them and have in the destination country before arrival; for example, partners can affect the propensity for self-employment both through the pooling of resources (Sanders and Nee 1996) and access to social capital (Kanas et al. 2009). Two variables are used to control for this. Firstly, whether the respondent knew someone in Sweden before migration, coded no or yes, is included. Secondly, a variable measuring partnership status, either in the form of marriage or cohabitation, is 
included. This is a time-varying variable included in the Cox regression and divided into three categories: single, partner from before migration, and partner from after migration. A respondent can at the time of arrival be either single or have a partner from before immigration, and the respondent can, during the time spent in Sweden, become single or get a partner after immigration.

Finally, there is a need to control for changing economic and labor market conditions on the macro level as well as individual push toward self-employment out of necessity. The former is controlled with calendar time, coded as five-year intervals but with extensions at the very first and very last period to not have too few observations. The respondents enter their migration year and then proceed chronologically with calendar time. The latter is controlled with individual employment status, a time-varying variable included in the Cox regression that indicates whether the respondent is employed. The variable is binary coded unemployed or employed based on answers from the employment biography of Migrant-LNU, wherein the respondents indicate their labor market activities with start and end dates.

\section{Results}

\section{Descriptive Statistics}

Table 1 displays descriptive statistics for the included variables. All numbers in the table, and in all tables except for sample size and the like, always carry a poststratification weighting in order to correspond to the immigrant population the sample is drawn from.

The average origin-country self-employment rate is 24 percent OCSE and 34 percent OCSE_FW. The correlation between the two measures, which is not visible in Table 1, is 0.88 . The most common regions of origin are the rest of Europe, the Middle East, and North Africa, with almost half of the (weighted) sample coming from these regions, whereas the least common is Sub-Saharan Africa and Latin America (see Table S1 in the online supplement for the most common countries and their regions).

Looking at individual experience before migration, 39 percent did not participate in the labor market before immigrating to Sweden, 54 percent have experience of employment only, and seven percent have experience of self-employment before migration. Sixteen percent of the sample have at some point been self-employed in Sweden, that is, have entered their first self-employment after immigration.

The average immigration age is 29.89 years. There are somewhat more females than males in the sample. The median highest achieved education level by the time of the survey is upper secondary, and most achieved their highest education level abroad. Thirty-five percent of the respondents have at least one parent who was self-employed during childhood. The most common reason for migration is family. Seventy-four percent knew someone in Sweden before migration.

Respondents in the sample were single 27 percent of the time, with a partner from before migration 31 percent of the time and with a partner starting after migration 42 percent of the time. The sample spent progressively more time in the later five-year intervals in Sweden. This is an effect of three factors. Firstly, immigration 
Table 1: Descriptive statistics

\begin{tabular}{|c|c|c|c|}
\hline & Range & Mean & SD \\
\hline OCSE & $0.00-0.94$ & 0.24 & 0.14 \\
\hline OCSE_FW & $0.00-0.96$ & 0.34 & 0.20 \\
\hline \multicolumn{4}{|l|}{ Region of origin } \\
\hline Nordic & $0 / 1$ & 0.20 & \\
\hline EU15+ & $0 / 1$ & 0.11 & \\
\hline Rest of Europe & $0 / 1$ & 0.25 & \\
\hline Middle East and North Africa & $0 / 1$ & 0.25 & \\
\hline Sub-Saharan Africa & $0 / 1$ & 0.05 & \\
\hline Rest of Asia & $0 / 1$ & 0.08 & \\
\hline Latin America & $0 / 1$ & 0.06 & \\
\hline \multicolumn{4}{|l|}{ Individual experience } \\
\hline No experience & $0 / 1$ & 0.39 & \\
\hline Employment only & $0 / 1$ & 0.54 & \\
\hline Self-employment & $0 / 1$ & 0.07 & \\
\hline Entered self-employment in Sweden & $0 / 1$ & 0.16 & \\
\hline Immigration age & $18.00-63.83$ & 29.89 & 8.20 \\
\hline \multicolumn{4}{|l|}{ Gender } \\
\hline Male & $0 / 1$ & 0.46 & \\
\hline Female & $0 / 1$ & 0.54 & \\
\hline \multicolumn{4}{|l|}{ Education level } \\
\hline Primary & $0 / 1$ & 0.25 & \\
\hline Upper secondary & $0 / 1$ & 0.39 & \\
\hline Postsecondary & $0 / 1$ & 0.37 & \\
\hline \multicolumn{4}{|l|}{ Place of highest education } \\
\hline Abroad & $0 / 1$ & 0.61 & \\
\hline Sweden & $0 / 1$ & 0.39 & \\
\hline \multicolumn{4}{|l|}{ Parents' self-employed } \\
\hline No/no parents & $0 / 1$ & 0.64 & \\
\hline Yes & $0 / 1$ & 0.36 & \\
\hline \multicolumn{4}{|l|}{ Migration reason } \\
\hline Work/studies/other & $0 / 1$ & 0.25 & \\
\hline Family & $0 / 1$ & 0.43 & \\
\hline Refuge & $0 / 1$ & 0.31 & \\
\hline \multicolumn{4}{|l|}{ Knew someone in Sweden } \\
\hline No & $0 / 1$ & 0.26 & \\
\hline Yes & $0 / 1$ & 0.74 & \\
\hline \multicolumn{4}{|l|}{ Partnership status ${ }^{a}$} \\
\hline Single & $0 / 1$ & 0.27 & \\
\hline Partner before immigration & $0 / 1$ & 0.31 & \\
\hline Partner after immigration & $0 / 1$ & 0.42 & \\
\hline \multicolumn{4}{|l|}{ Calendar time $^{a}$} \\
\hline Year 1955-1969 & $0 / 1$ & 0.03 & \\
\hline Year 1970-1974 & $0 / 1$ & 0.04 & \\
\hline Year 1975-1979 & $0 / 1$ & 0.06 & \\
\hline Year 1980-1984 & $0 / 1$ & 0.07 & \\
\hline Year 1985-1979 & $0 / 1$ & 0.09 & \\
\hline Year 1990-1994 & $0 / 1$ & 0.14 & \\
\hline Year 1995-1999 & $0 / 1$ & 0.16 & \\
\hline Year 2000-2004 & $0 / 1$ & 0.18 & \\
\hline Year 2005-2012 & $0 / 1$ & 0.23 & \\
\hline \multicolumn{4}{|l|}{ Employment status $^{a}$} \\
\hline Not employed & $0 / 1$ & 0.28 & \\
\hline Employed & $0 / 1$ & 0.72 & \\
\hline
\end{tabular}

${ }^{a}$ Mean value refers to the proportion of time spent in each respective state after immigration.

to Sweden has increased over time. Secondly, because the sample is delimited by the immigration ages 18 to 65 years, and the average immigration age is 29.89 , the 
most time these immigrants spend is after migration. Thirdly, it is a consequence of using survey, rather than registry, data. Individuals who migrated long ago have a lower probability of being in the target population because of emigration and mortality. Thus, it is good to remember that retrospective longitudinal data constructed from surveys does not represent everyone who ever immigrated but only those still present in the immigrant population. Finally, respondents in the sample spent 72 percent of the time being employed and, correspondingly, 28 percent not being employed after immigration.

\section{Immigrant Selection and Experience of Self-Employment}

The first analysis regards the connection between origin-country self-employment rates and the individual experience of immigrants (arrow 1a in Figure 1).

Table 2 provides an overview and displays the two ILO-based estimates of origin-country average rates of self-employment, OCSE and OCSE_FW, and the individual experience of self-employment before migration from Migrant-LNU (i.e., the proportion of the category self-employment in the variable individual experience). This is divided by region of origin. Three of the regions have additionally been divided into two cohorts each, either because of a long history of immigration to Sweden that is coupled with a gradual change in self-employment rates in the regions (Nordic and EU15+) or because of abrupt societal changes in the region (rest of Europe).

Two things are important to note in Table 2. The first is that immigrants from all region-cohort combinations, except for Nordic 1980-, have a lower actual experience of self-employment than might be expected given the origin-country rates. Clearly, the numbers measure somewhat different things, with the ILO-based numbers giving a snapshot of the proportion of employed individuals in a country who are self-employed, whereas Migrant-LNU numbers answer the question of how many have at some point been self-employed in the country of origin. Nonetheless, there are some stark contrasts, most notably for Sub-Saharan Africa, with a 77 percent average self-employment rate, including family workers, compared to only nine percent of immigrants from that region having preimmigration self-employment experience.

The second is that the variation in origin-country rates is not very informative of the individual experience that immigrants bring with them. Examining the two cohorts of Nordic or EU15+, respectively, the overall self-employment rates in these regions have gone down while at the same time individuals migrating in the latter cohorts have been self-employed more often. The sharp increase in experience of self-employment between the two cohorts for migrants from the rest of Europe is entirely missed by origin rates. Or consider the large variation of origin rates across the Middle East and North Africa, Sub-Saharan Africa, the rest of Asia, and Latin America, although about the same proportion of immigrants from those regions have been self-employed before migration to Sweden.

A linear probability model is used to test whether origin-country average rates of self-employ-

ment are predictive of individual experience (arrow 1a in Figure 1). The result is 
Table 2: Rates of self-employment before migration

\begin{tabular}{lccc}
\hline & $\begin{array}{c}\text { Origin-country rates } \\
\text { OCSE }\end{array}$ & $\begin{array}{c}\text { Individual experience } \\
\text { OCSE_FW }\end{array}$ & \begin{tabular}{c} 
Self-employment \\
\hline Nordic $-1979(\mathrm{~N}=147)$
\end{tabular} \\
Nordic $1980-(\mathrm{N}=119)$ & 0.15 & 0.23 & 0.03 \\
EU15+ -1979 $(\mathrm{N}=139)$ & 0.11 & 0.12 & 0.16 \\
EU15+ 1980- $(\mathrm{N}=244)$ & 0.14 & 0.24 & 0.03 \\
Rest of Europe -1989 $(\mathrm{N}=119)$ & 0.16 & 0.16 & 0.08 \\
Rest of Europe 1990- $(\mathrm{N}=152)$ & 0.18 & 0.28 & 0.01 \\
Middle East and North Africa $(\mathrm{N}=277)$ & 0.33 & 0.25 & 0.07 \\
Sub-Saharan Africa $(\mathrm{N}=251)$ & 0.54 & 0.77 & 0.10 \\
Rest of Asia $(\mathrm{N}=283)$ & 0.36 & 0.57 & 0.09 \\
Latin America $(\mathrm{N}=310)$ & 0.29 & 0.34 & 0.07 \\
\hline
\end{tabular}

shown in Figure 2 (see Table S2 in the online supplement for full results), where the dependent variable is individual experience, coded 1 if the individual had experience of self-employment before migration and 0 otherwise, and the independent variables are either OCSE or OCSE_FW at the country level, tested in separate models. This is done both without and with controls. The models without controls can be interpreted as a straightforward test of the country of origin approximation assumption; the models with controls are the partial correlation between the country-level measures and individual-level experience that is approximated in regressions of propensity for self-employment.

The largest coefficient, and thus the strongest predictor of individual experience, is OCSE without controls at 0.09 . This corresponds to, for example, a difference in predicted probability of having been self-employed of just 4.5 percentage points between two individuals coming from origins with 50 percentage points difference in self-employment rates. OCSE_FW has a coefficient of about half that size. It should also be noted that neither OCSE nor OCSE_FW are statistically significant at conventional levels, meaning that it cannot be excluded that there is zero association between the respective variable and individual experience. All things considered, the results clearly indicate that origin-country average rates of self-employment, no matter the measure, do not predict individual premigration experience very well.

\section{Human Capital and the Propensity for Self-Employment}

The second analysis is to estimate if experience of self-employment before migration can be used to predict entry into self-employment after migration and to investigate whether origin-country average rates can be used as a valid approximation in this prediction (arrows $1 \mathrm{~b}$ and 2 in Figure 1).

The sample in this part of the analysis is the same as in the first part, but following standard procedure for event-history analysis, the data has been transformed into a longitudinal setup. Respondents are followed from the month of immigration either until the month when they entered their first self-employment or until they 


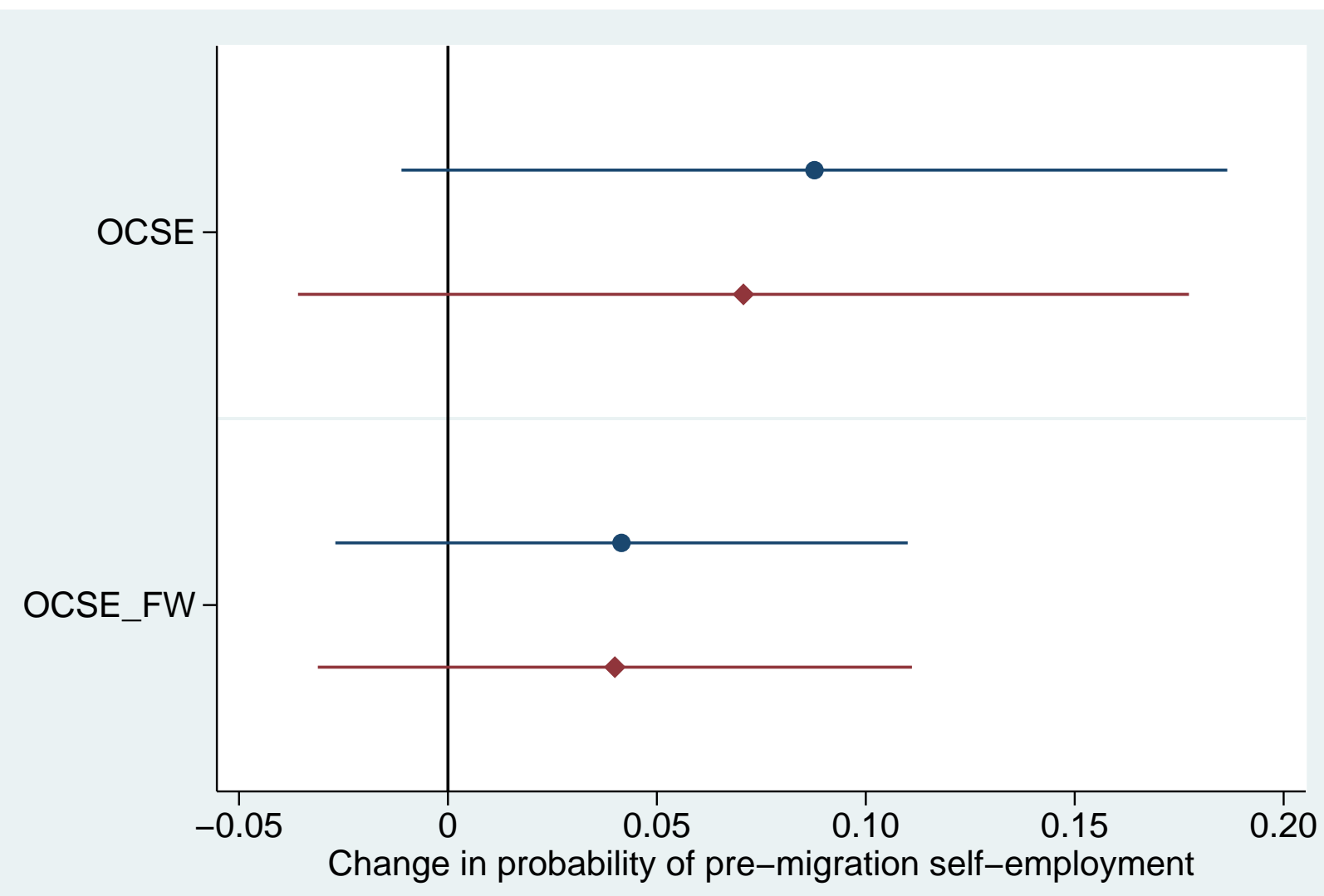

Without controls $\bullet$ With controls

Figure 2: Predicting individual experience of self-employment before migration. Regression results with 95 percent confidence intervals (from robust standard errors) for a linear probability model of OCSE and OCSE_FW on individual experience of self-employment are shown. See Table S2 in the online supplement for full results.

were dropped (right censored) for turning 65 years of age, or because the employment biography explicitly stated that they retired or signed off with long-term illness before the age of 65 , or at the month of the Migrant-LNU survey. Eleven respondents are excluded altogether from the analysis because they either migrated with their company or because they retired early, before migrating to Sweden.

Figure 3 contains the results from the Cox regressions (with full results in Table S3 in the online supplement). The dependent variable is entry into first selfemployment, and the main independent variables are OCSE, OCSE_FW, region of origin, and individual experience, which are tested in separate models. ${ }^{9}$ Each independent variable is also tested with and without controls, yielding eight models in total. Estimates for all variables are reported as exponentiated coefficients, that is, ratios of propensity to enter first self-employment. 


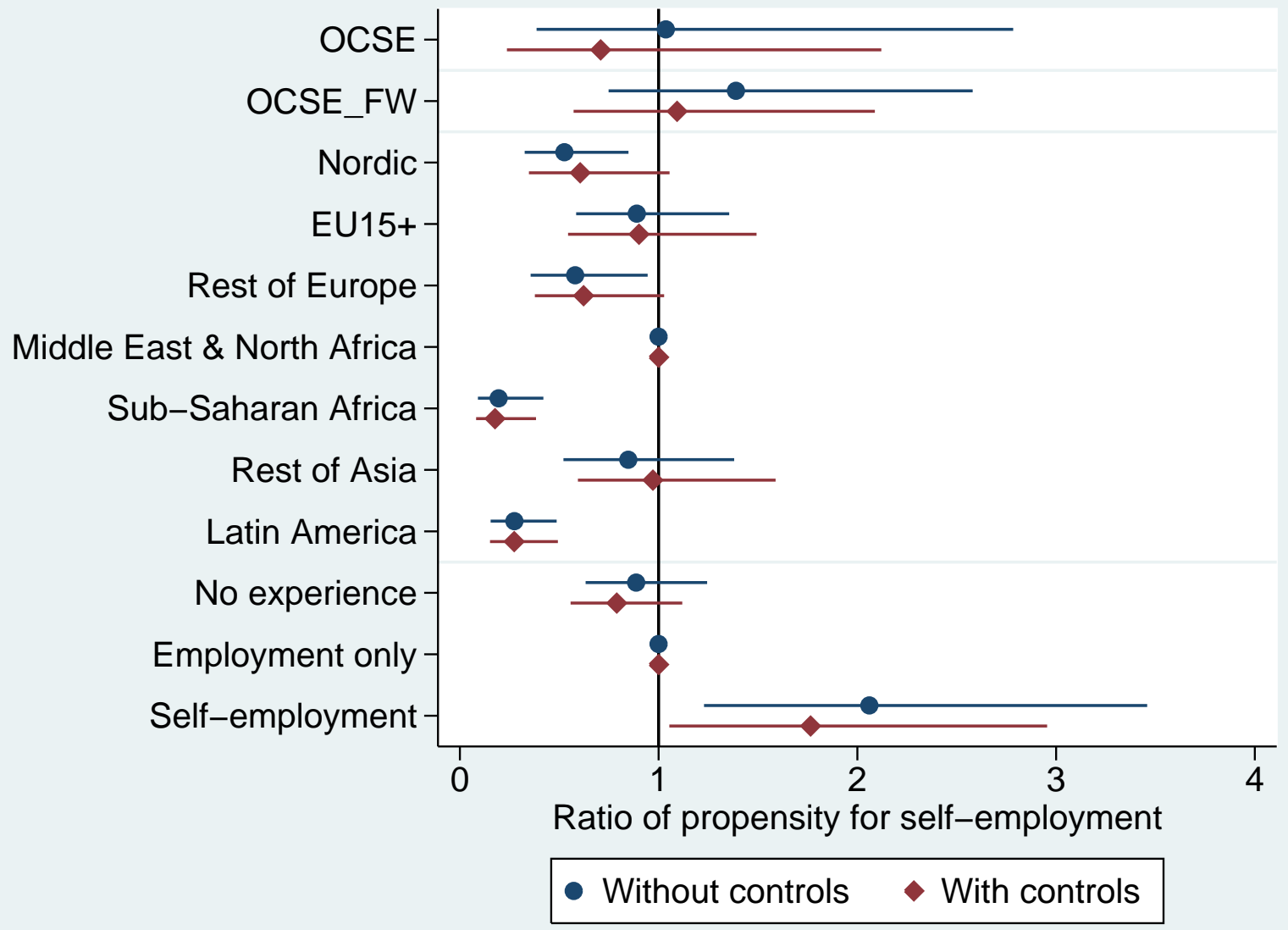

Figure 3: Propensity for self-employment using Cox regression. Regression results with 95 percent confidence intervals (from robust standard errors) for Cox regression, with time to entry into first self-employment as the dependent variable, are shown. See Table S3 in the online supplement for full results.

Starting with the origin-country average rates of self-employment, the strongest association with propensity for self-employment in Sweden is with the OCSE_FW variable without any controls. In that model specification, a difference of one percentage point in the origin-county rate is associated with an average of 0.3 -percenthigher probability of entering first self-employment. The association diminishes considerably when controls are included, and the variable without family workers, OCSE, has a weaker or even negative association with the probability of entering first-self-employment. In none of the four models are the variables close to being statistically significant at conventional levels.

Region of origin, with the Middle East and North Africa as the reference category, has some variation across different origins. In models in which controls are included, immigrants from Sub-Saharan Africa and Latin America have a substantially lower propensity for self-employment compared to immigrants from the Middle East and North Africa. However, relating these results to the origin-country average rates of self-employment in Table 2, it is clear that they have no meaningful connection to the home-country self-employment hypothesis, and it would be hard to argue that 
immigrants from, for example, the Middle East and North Africa arrive carrying an entrepreneurial culture, whereas immigrants from Sub-Saharan Africa do not (or that immigrants from EU15+ do).

Lastly comes the individual-level measure of experience. The reference category is set to be individuals with experience of employment only. After the inclusion of the controls in the final model, immigrants who had experience of self-employment before migration have an average of 76-percent-higher probability of entering their first self-employment compared to immigrants with premigration experience of employment only, and the difference is statistically significant at conventional levels. In contrast, the difference between immigrants with experience of employment only and no labor market experience is both smaller and statistically nonsignificant. The results suggest that there is specifically an association with previous experience of self-employment, not employment in general.

Figure 4 , based on the last model with controls, illustrates the variation in propensity to enter first self-employment between immigrants with different prior experience. The figure shows the predicted proportion who entered first selfemployment in Sweden at any given time since migration separated by the three categories of experience before migration and the three reasons for migration, the latter because each reason category has its own baseline transition rate due to stratification in the Cox regression. Taking family migration as the example, after 10 years (120 months), 24 percent of immigrants with premigration self-employment experience are predicted to have been self-employed at least once in Sweden, 34 percent after 20 years, and 42 percent after 30 years. The corresponding numbers for immigrants with premigration experience of employment only are 15, 21, and 27 percent, respectively.

Summarizing the results, the analyses clearly show that individual-level experience of self-employment before migration is connected to propensity for selfemployment in Sweden (arrow 2 in Figure 1). The analyses also show that using origin-country average rates of self-employment, or region of origin, as an approximation fails to capture this connection (arrow 1b in Figure 1).

\section{Robustness Checks}

Although the use of multiple-year records of OCSE and OCSE_FW is a step forward compared with previous research, there are also important limitations in that the ILO data is not complete for all years, creating gaps in measurement. The incompleteness is not random but varies with region (see Table S1 in the online supplement). Because of this, the more nuanced measurement could introduce bias in the analysis. In order to test how robust the results are, all the models with OCSE and OCSE_FW have been rerun with single-year records in three versions: earliest possible rate, latest possible rate, and average rate per country. The results, available upon request from the author, are essentially the same, with small, nonsignificant associations in both steps of the analysis.

A related issue regards the standard errors in models using the OCSE and OCSE_FW variables. Because not every individual is assigned a value specific to their unique country-year combination, but rather another year's self-employment 

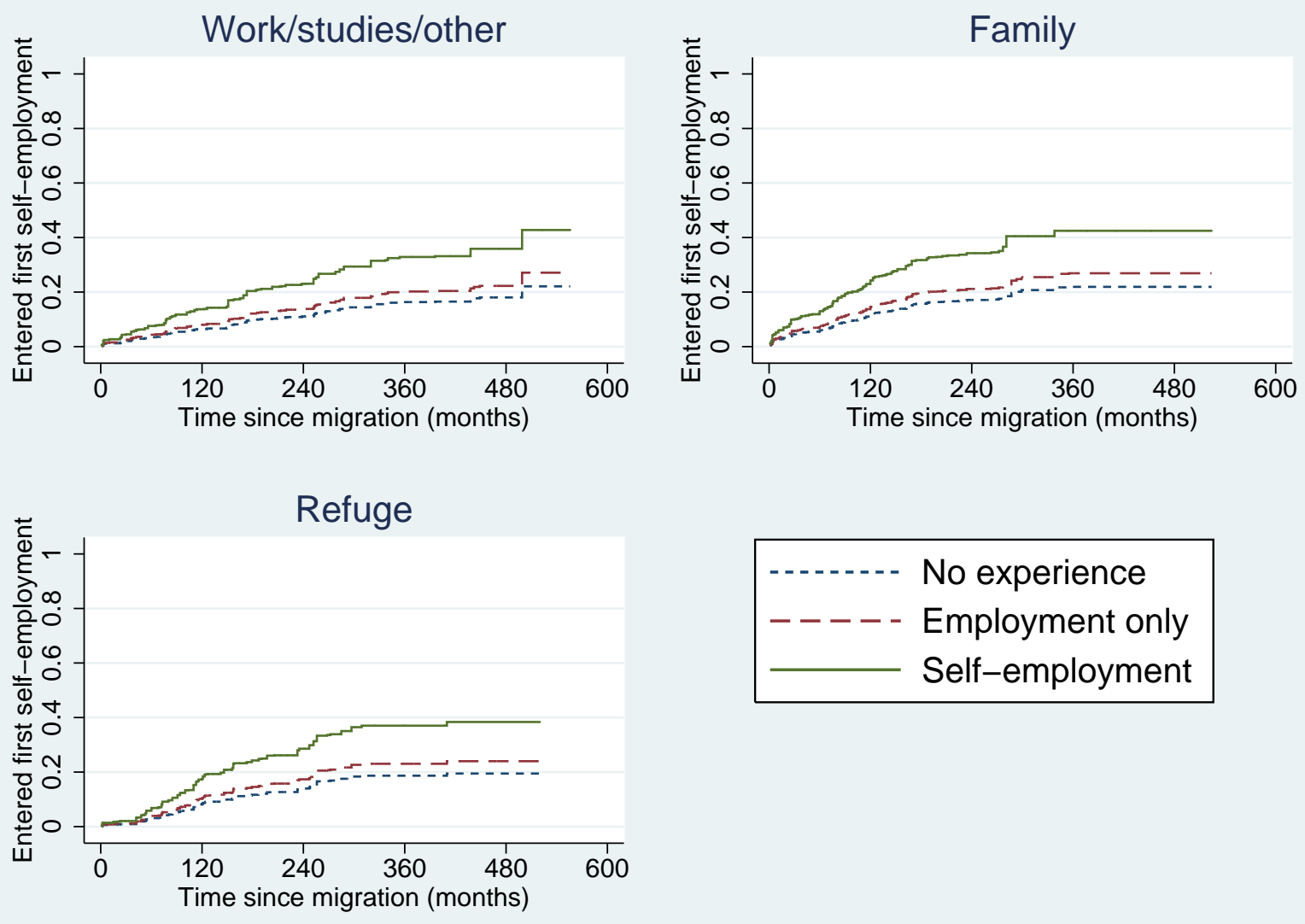

Figure 4: Cumulative entry into first self-employment by experience before immigration. Reversed survival curves are based on the last model in Figure 3 and Table S3.

rate within the same country, the observations are not entirely independent, potentially inducing artificial correlation in the error terms. The usual procedure to handle this is to use robust standard errors clustered on the origin country. However, the standard errors used here are already robust because of the poststratification weighting. In addition, the standard errors in the Cox regressions are clustered on the individual. ${ }^{10}$ As a sensitivity analysis, the OLS regressions in Figure 2 and Table S2 were refitted with standard errors clustered on origin country, which inflated the standard errors somewhat. However, this does not change any conclusion because OCSE and OCSE_FW were already not statistically significant at conventional levels.

Previous research has estimated propensity for self-employment using crosssectional design, contrasting self-employment and wage employment. To show that there is nothing artificial about the longitudinal setup and the Cox regression that drives the results, these analyses have been redone with OLS regression models with self-employment at the time of the survey as the dependent variable. Self-employment is binary coded 0 or 1 based on the questions of whether the 
respondents were self-employed, a family worker, or a freelancer in the week preceding the survey interview (if a respondent has multiple employments, the type that she or he considers the main one decided the coding). Following the standard of previous research, only those with some sort of employment are used in the sample and only those in the age span of 18 to 64 years (besides having immigrated after the age of 18). Because of the cross-sectional design, the time-varying variables from the Cox regression cannot be included. Calendar time has been replaced by years since migration, ${ }^{11}$ partnership status is measured by whether the respondent has a partner at the time of the survey, and employment status has been dropped. Descriptive statistics are shown in Table S4 and full results in Table S5 in the online supplement. In short, the results of the cross-sectional OLS parallel those of the Cox regressions, with individual experience predicting being self-employed, whereas origin-country average rates or region of origin do not. The predicted probability of someone with premigration experience of self-employment being self-employed at the time of the survey is 39 percent, compared to 15 percent for immigrants with premigration experience of employment only, at mean values for the other included variables. This is proportionally a much larger difference (2.60 times) than the result using Cox regression (1.76 times) and is, as discussed in the section on analytical strategy, an estimation that probably includes both the propensity for self-employment and the ability to keep a business going and is somewhat biased because it excludes individuals who are unemployed at the time of the survey.

\section{Concluding Discussion}

In their seminal review of ethnicity and entrepreneurship, Aldrich and Waldinger (1990:122) wrote that, "The selective nature of migration directs our attention to the human capital immigrants bring to their host societies." Following that notion, I have argued in this study that the home-country self-employment hypothesis is made up of two separate parts. One part concerns the measurement of individual experience using origin average rates of self-employment, here labeled the country-of-origin approximation assumption, and another part regards the connection between individual-level pre- and postmigration self-employment through the accumulation of entrepreneurial human capital, here labeled the entrepreneurial human capital hypothesis. The purpose has been to show that although the mechanism at the individual level is real, selection processes in migration make any countrylevel measurement biased, and this is why the home-country self-employment hypothesis, although intuitively reasonable, has underperformed empirically in previous research.

By using multiple-year measures of origin-country average rates of self-employment, and rates both without and with unpaid family workers, the country-of-origin approximation assumption has been given a better chance here than in any previous study. Yet, it failed every test. Analyzing immigrants in Sweden with the MigrantLNU survey, I found that the actual experience of self-employment before migration among immigrants is both considerably rarer than origin-country rates would suggest and varies across immigrant categories independently of them. Migrants seem to be too selective a population to be able to approximate with country-level 
measures. Consequently, none of the aggregate measures of self-employment before migration had any meaningful association with the propensity for self-employment in Sweden. Using the individual-level measure instead, immigrants with experience of self-employment have a 76-percent-higher propensity to start their first business in Sweden compared to immigrants with experience of employment only before migration. In summation, I find no support for the country-of-origin approximation assumption, but I find support for the entrepreneurial human capital hypothesis. The critique in this study against the use of aggregate measures for individual traits echoes the results of Ohlsson et al. (2012), who showed that country of origin misses almost all the variation concerning which immigrants become self-employed in Sweden, concluding that "it is the individual and not the immigrant/ethnic background that matters" (2012:420).

I believe the results to be generalizable outside of Sweden. Firstly, the result here for the aggregate measures is already in accordance with most of the previous research. It has only not been explained as due to migrant selection processes. Secondly, the mechanism of entrepreneurial human capital, derived from Borjas (1986) and Evans and Jovanovic (1989), should not be specific to the Swedish case.

Future research should move forward by always using individual-level measures and, besides testing replications of these results in other destination countries, explore further topics regarding the transferability of entrepreneurial human capital across national borders. One such topic is the generality of human capital. Throughout this study, it has been assumed that (a part of) entrepreneurial human capital is general enough that it transcends sector-specific experience of self-employment. Future research should try to measure what proportion of the entrepreneurial human capital is general and what is sector specific (i.e., the degree to which immigrants start businesses in the destination country that are in the same industry as they had in the origin country). In this way, the limits of entrepreneurial human capital may be addressed.

\section{Notes}

1 It is not stated why, but Hammarstedt and Shukur (2009) did not include immigrants from Chile or the former Yugoslavia in their analyses despite these being large immigrant populations in Sweden.

2 It is common to use the term hazard rate, but I will refrain from it because it has negative connotations for readers who are not used to event-history analysis.

3 All cited studies that test the home-country self-employment hypothesis use a crosssectional design.

4 This problem was stressed already 30 years ago: "The probability of being self-employed at time $\mathrm{T}$ depends upon the underlying probability of switching into self-employment at some previous time and surviving until time T. The cross-sectional estimates confound the determinants of switching and survival." (Evans and Leighton 1989:529)

5 Aharon (2017) does not specify the year. Akee et al. (2013) use rates from 1995 to 2000. Fairlie and Meyer (1996) separately test 1970 or the closest available year and "the beginning of the median decade of immigration" (1996:779) for respective immigrant category. Hammarstedt and Shukur (2009) separately test rates from the 1970s and the 
1990s. van Tubergen (2005) uses rates from 1980 to 1990. Yuengert (1995) uses rates from 1969.

6 Modeled estimates are used for Eritrea, Somalia, and Uzbekistan.

7 Respondents in Migrant-LNU could, besides a specific month, answer quarter (coded as the midquarter month) and unknown month (coded as July).

8 Other is a small category, mostly comprised of de facto work, studies, and family migrants from the Nordic and EU countries.

9 Because the four main variables are all operationalizations of the same underlying concept (experience before migration), it would be theoretically unwise to include more than one of them in the same model. Having said that, including either OCSE, OCSE_FW, or region of origin in a model with individual experience does not change the result for the latter in any substantial way. This follows logically from the fact that the aggregate measures are uncorrelated with individual experience before migration, as was evident in the preceding analysis.

10 It should also be noted that because the sample is drawn in Sweden, not in the respondent's respective origin countries, clustering due to sample design is not relevant when neither OCSE nor OCSE_FW is used (Abadie et al. 2017).

11 In a cross-sectional design, the variable years since migration can be interpreted both as an effect of time spent in the destination country and as (the entry conditions during) the year of immigration. An inclusion of a squared term of years since migration does not improve the model and is therefore excluded for multicollinearity reasons.

\section{References}

Abada, Teresa, Feng Hou, and Yuqian Lu. 2014. "Choice or Necessity: Do Immigrants and Their Children Choose Self-Employment for the Same Reasons?" Work, Employment and Society 28:78-94. https ://doi .org/10.1177/0950017013511870.

Abadie, Alberto, Susan Athey, Guido W. Imbens, and Jeffrey M. Wooldridge. 2017. "When Should You Adjust Standard Errors for Clustering?" Working Paper Series No. 24003, National Bureau of Economic Research. https://doi.org/10.3386/w24003.

Aharon, Galit. 2017. "Self-Employment of Immigrant Women in the United States: The Role of Country-of-Origin and Family-Related Policies." Social Science Research 63:277-91. https://doi.org/10.1016/j.ssresearch.2016.09.020.

Akee, Randall K. Q., David A. Jaeger, and Konstantinos Tatsiramos. 2013. "The Persistence of Self-Employment Across Borders: New Evidence on Legal Immigrants to the United States." Economics Bulletin 33:126-37.

Aldrich, Howard E., and Roger Waldinger. 1990. "Ethnicity and Entrepreneurship." Annual Review of Sociology 16:111-35.

Aliaga-Isla, Rocío, and Alex Rialp. 2013. "Systematic Review of Immigrant Entrepreneurship Literature: Previous Findings and Ways Forward." Entrepreneurship and Regional Development 25:819-44. https://doi .org/10.1080/08985626.2013.845694.

Alvarez, Sharon A., Rajshree Agarwal, and Olav Sorenson. 2005. Handbook of Entrepreneurship Research: Disciplinary Perspectives. New York, NY: Springer.

Andersson Joona, Pernilla. 2010. "Exits from Self-Employment: Is There a Native-Immigrant Difference in Sweden?" International Migration Review 44:539-59. https : //doi .org/10. $1111 / \mathrm{j} .1747-7379.2010 .00817 . x$. 
Andersson Joona, Pernilla. 2011. "The Native-Immigrant Income Gap among the SelfEmployed in Sweden." International Migration 49:118-43. https://doi .org/10.1111/j . 1468-2435.2009.00510.x.

Andersson Joona, Pernilla, and Eskil Wadensjö. 2012. "Being Employed by a Co-National: A Cul-de-sac or a Short Cut to the Main Road of the Labour Market?" Journal of International Migration and Integration 13:99-120. https://doi .org/10.1007/s12134-011-0195-3.

Andersson, Lina. 2011. "Occupational Choice and Returns to Self-employment among Immigrants." International Journal of Manpower 32:900-22. https://doi .org/10.1108/ 01437721111181660.

Andersson, Lina, and Mats Hammarstedt. 2011. "Transmission of Self-Employment across Immigrant Generations: The Importance of Ethnic Background and Gender." Review of Economics of the Household 9:555-77. https ://doi .org/10.1007/s11150-010-9102-5.

Andersson, Lina, Mats Hammarstedt, Shakir Hussain, and Ghazi Shukur. 2013. "Ethnic Origin, Local Labour Markets and Self-Employment in Sweden: A Multilevel Approach." Annals of Regional Science 50:885-910. https://doi .org/10.1007/s00168-012-0525-1.

Behtoui, Alireza, and Anders Neergaard. 2010. "Social Capital and Wage Disadvantages among Immigrant Workers." Work, Employment and Society 24:761-79. https : //doi .org/ 10.1177/0950017010380640.

Birgier, Debora Pricila, Christer Lundh, Yitchak Haberfeld, and Erik Elldér. 2018. "SelfSelection and Host Country Context in the Economic Assimilation of Political Refugees in the United States, Sweden, and Israel." International Migration Review 52:524-58.

Blossfeld, Hans Peter, Katrin Golsch, and Gotz Rohwer. 2007. Event History Analysis Using Stata. New York, NY: Psychology Press.

Blume, Kræn, Mette Ejrnæs, Helena Skyt Nielsen, and Allan Würtz. 2009. "Labor Market Transitions of Immigrants with Emphasis on Marginalization and Self-Employment." Journal of Population Economics 22:881-908. https : //doi .org/10.1007/s00148-008-0191-x.

Borjas, George J. 1986. "The Self-Employment Experience of Immigrants." The Journal of Human Resources 21:485-506.

Borjas, George J. 1989. "Economic Theory and International Migration." International Migration Review 23:457-85.

Boyle, Paul J., Keith H. Halfacree, and Vaughan Robinson. 2013. Exploring Contemporary Migration. London, United Kingdom: Routledge.

Bursell, Moa. 2014. "The Multiple Burdens of Foreign-Named Men-Evidence from a Field Experiment on Gendered Ethnic Hiring Discrimination in Sweden." European Sociological Review 30:399-409. https://doi .org/10.1093/esr/jcu047.

Clark, Kenneth, and Stephen Drinkwater. 2000. "Pushed Out or Pulled In? Self-Employment among Ethnic Minorities in England and Wales." Labour Economics 7:603-28. https: //doi.org/10.1016/s0927-5371(00)00015-4.

Cox, David R. 1972. "Regression Models and Life-Tables." Journal of the Royal Statistical Society. Series B (Methodological) 34:187-220. https://doi .org/10.1111/j.2517-6161. 1972.tb00899.x.

Dahl, Michael S., and Olav Sorenson. 2009. "The Embedded Entrepreneur." European Management Review 6:172-81.

de Haas, Hein, Katharina Natter, and Simona Vezzoli. 2018. "Growing Restrictiveness or Changing Selection? The Nature and Evolution of Migration Policies." International Migration Review 52:324-67. 
Drinkwater, Stephen, and Ken Clark. 2009. "Immigrant Self-Employment Adjustment: Ethnic Groups in the UK." International Journal of Manpower 30:163-75. https://doi .org/10. 1108/01437720910948465.

Dunn, Thomas, and Douglas Holtz-Eakin. 2000. "Financial Capital, Human Capital, and the Transition to Self-Employment: Evidence from Intergenerational Links." Journal of Labor Economics 18:282-305. https://doi.org/10.1086/209959.

Ekberg, Jan, and Mats Hammarstedt. 2002. "20 År Med Allt Sämrearbetsmarknadsintegrering För Invandrare." Ekonomisk Debatt 30:343-53.

Evans, David S., and Boyan Jovanovic. 1989. "An Estimated Model of Entrepreneurial Choice under Liquidity Constraints." Journal of Political Economy 97:808.

Evans, David S., and Linda S. Leighton. 1989. "Some Empirical Aspects of Entrepreneurship." The American Economic Review 79:519. https://doi.org/10.1086/261629.

Fairlie, Robert W., and Bruce D. Meyer. 1996. "Ethnic and Racial Self-Employment Differences and Possible Explanations." The Journal of Human Resources 31:757-93. https : / doi . org/ $10.2307 / 146146$.

Government of the Kingdom of Sweden. 1999. Immigrants as Entrepreneurs. For Equal Opportunities and Increased Growth. Stockholm, Sweden: Fakta Info Direkt.

Haberfeld, Yitchak, and Christer Lundh. 2014. "Self-Selection and Economic Assimilation of Immigrants: The Case of Iranian Immigrants Arriving to Three Countries During 19791985." International Migration Review 48:354-86. https : //doi .org/10.1111/imre. 12080.

Hammarstedt, Mats, and Ghazi Shukur. 2009. "Testing the Home-Country Self-Employment Hypothesis on Immigrants in Sweden." Applied Economics Letters 16:745-8. https://doi . org/10.1080/13504850701221907.

Hjerm, Mikael. 2004. "Immigrant Entrepreneurship in the Swedish Welfare State." Sociology 38:739-56. https://doi.org/10.1177/0038038504045862.

Hout, Michael, and Harvey Rosen. 2000. "Self-Employment, Family Background, and Race." The Journal of Human Resources 35:670-92. https ://doi . org/10 . 2307/146367.

Ichou, Mathieu. 2014. "Who They Were There: Immigrants' Educational Selectivity and Their Children's Educational Attainment." European Sociological Review 30:750-65. https : //doi.org/10.1093/esr/jcu071.

International Labour Organization. Annual. Yearbooks for Labour Statistics. Geneva, Switzerland: International Labour Organization.

International Labour Organization. 2018. "Status in Employment - ILO Modelled Estimates." Retrieved April 10, 2019 (https://www.ilo.org/ilostat/faces/ oracle/webcenter/portalapp/pagehierarchy/Page3 $\backslash$. jspx; ILOSTATCOOKIE= MIYHOgwpE8hx_qZedv42DMEi_KH_nlw8t9Z2mLhP2Jy_Kl1 \UT3vB! 1567639201 ?

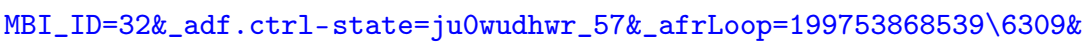
_afrWindowMode=0\&_afrWindowId=null\#! $\% 40 \% 40 \% 3 \mathrm{~F}$ _afrWindowId $\% 3 \mathrm{Dnul} 1 \% \backslash 26$ _ afrLoop\%3D1997538685396309\%26MBI_ID\%3D32\%26_afrWindowMode\%3D0\%26_\adf . ctrl-state\%3Ddfupvzvtt_4).

International Labour Organization. 2019. "Employment by Sex and Status in Employment." Retrieved April 10, 2019 (https://www.ilo.org/ilostat/faces/oracle/webcenter/ portalapp/pagehierarchy/Page27. \jspx?subject=EMP\&indicator=EMP_TEMP_ SEX_STE_NB\&datasetCode=A\&collection $\backslash$ Code $=$ YI\&_af $r$ Loop $=1548846880893766 \&$ _afrWindowMode=0\&_afrWindowId=1b6af w5v $\backslash$ dq_ $1 \#$ ! $\% 40 \% 40 \% 3$ Findicator $\% 3 D E M P \_$ TEMP_SEX_STE_NB\%26_afrWindowId\%3D1b6af \w5vdq_1\%26subject\%3DEMP\%26_ afrLoop $\% 3$ D $1548846880893766 \% 26$ datasetCode $\% 3 D A \backslash \% 26$ collectionCode $\% 3 D Y I \%$ 26_afrWindowMode\%3D0\%26_adf .ctrl-state\%3D1b6afw5vdq_57). 
Kanas, Agnieszka, Frank van Tubergen, and Tanja van der Lippe. 2009. "Immigrant SelfEmployment: Testing Hypotheses About the Role of Origin- and Host-Country Human Capital and Bonding and Bridging Social Capital." Work and Occupations 36:181-208. https://doi.org/10.1177/0730888409340128.

Kloosterman, Robert C. 2010. "Matching Opportunities with Resources: A Framework for Analysing (Migrant) Entrepreneurship from a Mixed Embeddedness Perspective." Entrepreneurship and Regional Development 22:25-45. https://doi .org/10.1080/ 08985620903220488.

Kloosterman, Robert, Joanne van der Leun, and Jan Rath. 1999. "Mixed Embeddedness: (In)formal Economic Activities and Immigrant Businesses in the Netherlands." International Journal of Urban and Regional Research 23:252. https://doi .org/10.1111/ $1468-2427.00194$.

Kloosterman, Robert, and Jan Rath. 2001. "Immigrant Entrepreneurs in Advanced Economies: Mixed Embeddedness Further Explored." Journal of Ethnic and Migration Studies 27:189201. https://doi.org/10.1080/13691830020041561.

Le, Anh T. 2000. "The Determinants of Immigrant Self-Employment in Australia." International Migration Review 34:183-214. https://doi .org/10.1177/019791830003400108.

Lee, Everett S. 1966. "A Theory of Migration." Demography 3:47-57.

Li, Peter S. 2001. "Immigrants' Propensity to Self-Employment: Evidence from Canada." International Migration Review 35:1106-28. https ://doi .org/10.1111/j.1747-7379.2001. tb00054.x.

Light, Ivan. 1984. "Immigrant and Ethic Enterprise in North America." Ethnic and Racial Studies 7:195-216. https://doi.org/10.1080/01419870.1984.9993441.

Lofstrom, Magnus. 2002. "Labor Market Assimilation and the Self-Employment Decision of Immigrant Entrepreneurs." Journal of Population Economics 15:83-114. https ://doi .org/ $10.1007 / \mathrm{pl} 00003841$.

Lundh, Christer, and Rolf Ohlsson. 1999. Från Arbetskraftsimport Till Flyktinginvandring Stockholm, Sweden: Studieförbundet Näringsliv och Samhälle.

Massey, Douglas S., Joaquin Arango, Graeme Hugo, Ali Kouaouci, Adela Pellegrino, and J. Edward Taylor. 1993. "Theories of International Migration: A Review and Appraisal." Population and Development Review 19:431-66. https://doi .org/10. 2307/2938462.

Ohlsson, Henrik, Per Broomé, and Pieter Bevelander. 2012. "Self-Employment of Immigrants and Natives in Sweden - A Multilevel Analysis." Entrepreneurship and Regional Development 24:405-23. https://doi.org/10.1080/08985626.2011.598570.

Piore, Michael J. 1979. Birds of Passage: Migrant Labor and Industrial Societies. Cambridge, United Kingdom: Cambridge University Press. https://doi.org/10.1017/ s0047279400010576.

Polavieja, Javier G., Mariña Fernández-Reino, and María Ramos. 2018. "Are Migrants Selected on Motivational Orientations? Selectivity Patterns Amongst International Migrants in Europe." European Sociological Review 34:570-88. https://doi .org/10.1093/ esr/jcy025.

Rosholm, Michael, Kirk Scott, and Leif Husted. 2006. "The Times They Are a-Changin': Declining Immigrant Employment Opportunities in Scandinavia." International Migration Review 40:318-47. https://doi .org/10.1111/j.1747-7379.2006.00019.x.

Sanders, Jimy M., and Victor Nee. 1996. "Immigrant Self-Employment: The Family as Social Capital and the Value of Human Capital." American Sociological Review 61:231-49. https://doi.org/10.2307/2096333. 
Slavnic, Zoran. 2010. "Political Economy of Informalization." European Societies 12:3-23. https://doi.org/10.1080/14616690903042724.

Sorenson, Olav, and Pino G. Audia. 2000. "The Social Structure of Entrepreneurial Activity: Geographic Concentration of Footwear Production in the United States, 1940-1989." American Journal of Sociology 106:424-62. https : //doi .org/10 . 1086/316962.

Swedish Institute for Social Research. 2017. "The Swedish Level-of-Living Survey (LNU)." Retrieved April 10, 2019 (https://www.sofi.su.se/ english/2.17851/research/three-research-units/lnu-level-of-living/ the-swedish-level-of-living-survey-lnu-1.65112).

Tibajev, Andrey, and Carina Hellgren. 2019. "The Effects of Recognition of Foreign Education for Newly Arrived Immigrants." European Sociological Review 35:506-21. https://doi . org/10.1093/esr/jcz011.

Tomaskovic-Devey, Donald, Martin Hällsten, and Dustin Avent-Holt. 2015. "Where Do Immigrants Fare Worse? Modeling Workplace Wage Gap Variation with Longitudinal Employer-Employee Data." American Journal of Sociology 120:1095-143. https://doi. org/10.1086/679191.

van de Werfhorst, Herman G., and Anthony Heath. 2019. "Selectivity of Migration and the Educational Disadvantages of Second-Generation Immigrants in Ten Host Societies." European Journal of Population 35:347-78. https : //doi .org/10.1007/s10680-018-9484-2.

van Tubergen, Frank. 2005. "Self-Employment of Immigrants: A Cross-National Study of 17 Western Societies." Social Forces 84:709-32. https ://doi .org/10.1353/sof . 2006. 0039.

Warnes, Tony. 1992. "Migration and the Life Course." Pp. 175-87 in Migration Processes and Patterns. Research Progress and Prospects. Vol. 1, edited by T. Champion and T. Fielding. London, United Kingdom: Belhaven.

Webster, Natasha A., and Karen Haandrikman. 2017. "Thai Women Entrepreneurs in Sweden: Critical Perspectives on Migrant Small Businesses." Women's Studies International Forum 60:17-27. https://doi.org/10.1016/j.wsif .2016.11.001.

Yuengert, Andrew M. 1995. "Testing Hypotheses of Immigrant Self-Employment." The Journal of Human Resources 30:194-204. https ://doi .org/10 . 2307/146196.

Zhou, Min. 2004. "Revisiting Ethnic Entrepreneurship: Convergencies, Controversies, and Conceptual Advancements." International Migration Review 38:1040-74. https://doi. org/10.1111/j.1747-7379.2004.tb00228.x.

Zwysen, Wouter. 2019. "Different Patterns of Labor Market Integration by Migration Motivation in Europe: The Role of Host Country Human Capital." International Migration Review 53:59-89. https://doi.org/10.1177/0197918318767929.

Acknowledgments: I am grateful for insightful comments from Moa Bursell, Martin Hällsten, Karin Krifors, Olav Nygård, Ognjen Obucina and Zoran Slavnic as well as the conference participants of the European Consortium for Sociological Research Annual Conference in Paris and International Migration, Integration, and Social Cohesion Annual Conference in Barcelona.

Andrey Tibajev: Institute for Research on Migration, Ethnicity and Society, Linköping University. E-mail: andti116@student.liu.se. 